\title{
Nishizuru, Chapei, and so on: The Representation of Crisis in Kazuo Ishiguro's Novels
}

\author{
Motoko Sugano
}

\begin{abstract}
This paper examines a particular representation of crisis in Kazuo Ishiguro's novels. It focuses on two separate surprisingly similar literary constructions of poor district, and considers the implications of the ways in which the crisis of the times is presented. First, I look at the "Nishizuru" district of slums included in Ishiguro's second novel, An Artist of the Floating World (1986). Second, I consider "Chapei," an extremely crowded Chinese quarter and front for a war between the Japanese and Chinese in his fifth novel, When We Were Orphans (2000). To address the issue of crisis, I would like to tentatively define the word as referring to "the state of the nation," or to use a more prominent term, the "Condition of England." This term was coined by Thomas Carlyle in Chartism (1837) and Past and Present (1843) to reference the alarming nature of a problem that originated in industrialization and the rapid changes it brought to English society. Carlyle's concern reverberates in some of the contemporary British fictions published in the 1980s and 1990s during, when the British economy underwent neoliberal restructuring. Hence, this presentation discusses how Ishiguro's fiction responds to contemporary manifestations of the "Condition of England" debate.
\end{abstract}

Index Terms-Representation, crisis, nishizuru, chapei.

\section{INTRODUCTION}

This paper examines the representation of crisis in Kazuo Ishiguro's novels. To address this issue, I would like to tentatively define the crisis. In this paper, I use it in a reference to the state of the nation - the term that is used both generally and specifically. When it is discussed in English literature, however, one assumes that the term refers to a particular condition of the nation known as the "Condition of England" coined by Thomas Carlyle in Chartism (1837) and in Past and Present (1843). By this term, Carlyle describes his concern about the rapid social changes stemming from the ongoing process of industrialization. $\mathrm{He}$ is particularly concerned about issues related to working class militancy and poverty, describing the condition as one of the most "ominous" and "strangest" phenomena that has "ever existed in the world." [1] He calls for immediate actions to alleviate a situation that Parliament has continuously failed to control.

Many of Carlyle's influential and powerful contemporaries answered his call for action was responded by many people of his contemporary with considerable

Manuscript received September 15, 2013; revised November 20, 2013. This work was supported in part by Japan Ministry of Education, Culture, Sports, Science and Technology (MEXT) and the Japan Society for the Promotion of Science (JSPS) under Grants-in-Aid for Scientific Studies 23520336

Motoko Sugano is with the Tsurumi University, 2-1-3 Tsurumi, Tsurumi-ku, Yokohama, Kanagawa, 230-8501, Japan (e-mail: sugano-m@tsurumi-u.ac.jp). influence and power, including some novelists who responded to the "condition of England" in the form of fiction. The "Condition of England" novel discusses issues such as poverty, factory works, and class division. [2]-[6]. Despite fundamental changes in the material condition of English society's working class, the concept and literary conventions used in the "Condition of England" novel have been reinvented in present day social and economic condition. It was a time when the income gap between the rich and poor or the North and South increased, [7] and the issue of poverty emerged under a conservative government whose leader legitimized changes by relating her ideals to Victorian morality [8].

Since the publication of his first novel in 1982, Kazuo Ishiguro has been a novelist among his contemporaries interested in responding to the "condition of England." Ishiguro confesses that he is obsessed with the "myths of England," the ways in which England or the English people are discursively constructed and accepted as truth. [9] Although such a creative impetus is most evident in his "English" novels such as The Remains of the Day (1989) or Never Let Me Go (2005), his other works can also be read as an exploration of the English condition. Ishiguro's "Japanese" novels such as A Pale View of Hills (1982) and An Artist of the Floating World (1986) are set in Japan, although they are not exactly investigations of Japanese history or society. [10] What is his concern then, and why do his "Japanese" novels seem to address issues relevant to contemporary England? It would be more fitting to consider both novels a prelude to The Remains of the Day, the final work in Ishiguro's trilogy, where he fully explores the contemporary "Condition of England." In his other more international novels such as The Unconsoled (1995) and When We Were Orphans (2000), the setting shuffles between England and other places, even though these novels are not exactly about their locations. [11], [12] The English narrators of both The Unconsoled and When We Were Orphans express concern for England, and struggle with issues of anxiety and belonging. As such, it can be said that Ishiguro's novels both directly and indirectly deal with issues relate to the contemporary condition of England.

In the following discussion, I examine the representation of crisis in Ishiguro's second novel An Artist of the Floating World (hereafter Artist), and his fifth novel When We Were Orphans (hereafter Orphans). As I explain later, the Nishizuru district depicted in Artist and Chapei in Orphans are similar in some ways. Although existing criticism of Ishiguro has paid little attention to the implications of the Nishizuru district, its significance will become clearer by comparing it to Chapei and considering Ishiguro's self-referentiality. I suggest that both narratives can be read as political fables of failure in which a socially influential and 
respected figure not only fails to deal with the critical condition of poverty, but also misrepresents the impoverished. Their first-hand accounts provide a glimpse into the lives of the local underclass, though it does not lead to an improved understanding of their condition, and in fact misleads them. Such failures resonate with what Carlyle expressed as the "condition of England," where people in power discuss problems but fail to resolve them [13], they neither understand nor effectively represent the poor. Ishiguro's novels present a crisis, and just like the "Condition of England" novels of the mid- $19^{\text {th }}$ century, it is left unresolved. In other words, poverty is perceived to be a humanitarian dilemma as well as a burden for the ruling class.

\section{The NishizURU District IN AN ARTIST OF THE FLOATING WORLD}

Artist is Kazuo Ishiguro's second novel and the first and only novel to be set entirely in Japan. Masuji Ono is the novel's narrator, an elderly Japanese man and former painter. However, he retired from art following the war due to his promotion of militarist causes during the war. Ono's narrative dates from October 1948 to June 1950. His narrative is extremely ambivalent concerning his past conduct, which inevitably affects his position in a post-war society; despite his errors, he maintained that he never intended to do anything wrong.

Ono recollects his introduction to Nishizuru, a slum district, by Chishu Matsuda, a social nationalist ideologue. Matsuda brings Ono to Nishizuru to show the condition of inhabitants and, by so doing so, opens his eyes to social injustice. Upon first seeing the slum from a bridge, Ono narrates that:

The view below us was framed by two factory plants looming one to the right, the other to our left. Wedged in between was a dense muddle of roofs, some of the cheap shingled variety, others impoverished out of corrugated materials. ... Viewed from the bridge, a stranger may well have assumed that community to be some derelict site half-way to demolition were it not for many small figures, visible on closer inspection, moving busily around the houses like ant swarming around stones [14].

Poverty in Nishizuru is associated with factory labor and poor living conditions. Its existence is in crisis, and Ono describes it as "derelict site half-way to demolition." The area is dehumanizing in two senses. First, its living conditions are inhumane and described as small, crowded and disorderly. Second, Ono initially fails to identify the residents as people; once he does, he refers to them as insects. Even from the onset, it is obvious that the living conditions in Nishizuru are desperate, and Ono's depiction suggests that he is both a physical and cultural outside to the district.

Ono's companion Matsuda further characterizes Nishizuru as being evil and contaminating. His description of Nishizuru is more authoritative than Ono's, since he knows the area quite well. Matsuda's depiction of the area is characterized by feelings of contempt and disgust. He remarks that the area is reeks of sewage, and refers to the smell as "bad fungus." [14] As the population transitions from farm labor in the countryside to industrial work in the city, more districts like
Nishizuru are emerging: areas without proper sewage systems and continuously increasing populations. Aside from poor hygiene standards, Matsuda considers Nishizuru geographically "unwanted." The district's main road provides a short cut to town. If Nishizuru were demolished and redeveloped, the path would be more easily accessible. Matsuda clearly characterizes the area as evil and unwelcoming; Nishizuru is already in near ruins, and he justifies its neglected condition.

When the pair actually take a short cut, Ono finds that the homes are in extremely close proximity, sometimes separated by a mere sheet of paper or cloth, suggesting that human dignity can be sustained by cheap and affordable materials not suitable for construction purposes. While the building materials indicate poverty and vulnerability, neither character describes the homes in great details. For example, there is no information suggesting their shapes, patterns, or designs. Similarly, Ono's depiction of the population tends to generalize their features; they are referred to as "old people," "small children," "crying babies," and "neighbours chatting amiably." [14] In short, the place is given a name, but all other details are absent.

Ono reinvents these crises to create other representations of crises. That is, crisis in the state order. When Ono traveled through Nishizuru, he witnessed three boys torturing something with sticks. On being noticed, the boys display guilty smiles. This encounter inspires Ono to produce a propaganda poster entitled "Complacency" in which three boys are transformed into young samurai warriors, holding Kendo sticks in front of shanties with a slogan stating that "but the young are ready to fight for their dignity." [14] In this work, the shanties signify poverty and the slogan depicts poverty as an undignified way of life, thus urging the Japanese samurai for modern life and wealth. Later, the painting is revised by Ono and titled "Eye to the Horizon." In the picture, the three samurais are replaced with "stern faced soldiers" brandishing rifles aimed towards Asia. The shanties in the background are replaced with the image of a rising sun [14]. The new slogan is read "No more cowardly talking now. Japan must go forward," [14] promoting colonial expansion in Asia. In the second painting, the alarming condition of poverty that inspired Ono's original work has been superseded by militarist propaganda.

\section{Chapei IN When WE Were ORPHANS}

As if to evoke a response from Asia to which the three rifles were directed, Ishiguro's fifth novel, Orphans is partly set in Shanghai under colonial occupation. In the novel, Ishiguro reinvents a district of crisis in the name of Chapei in Shanghai.

Orphans is narrated by Christopher Banks, who like Masuji Ono of Artist, is both the story's main character and narrator, and his narrative dates from the year 1930 to 1958 , shuffling between the past and present, London and Shanghai. The narrator Banks was born in Shanghai's International Settlement in early $20^{\text {th }}$ century, but repatriated to England at the age of seven after his parents mysteriously disappeared. He was educated at a public school, studied at Cambridge, and unlike many of his classmates, became a private detective. Detective Banks returns to Shanghai in September 
1937, twenty-five years after from his parents' disappearance to rescue them from their captures in Chapei.

The poor district in this novel, Chapei, is a Shanghai living quarter comprising local Chinese people, who are oppressed by both European and Japanese imperial forces. Some of the discourses present Nishizuru are also apparent in the description of Chapei. When Banks was a boy, he was told to never go to the Chinese quarters because the place it was full of "ghostly diseases, filth and evil men."[15]. He remembered how he saw the "huddled low rooftops" of the Chinese district on the other bank of Soochow creek. [15] His friend Akira was more knowledgeable of the quarter. In the passage below, Banks recalls what Akira told him about it:

There were no proper buildings, just shacks upon shacks built in great proximity to one another. It all looked, he claimed, much like the marketplace in Boone Road, except that whole families were to be found living in each "stall." There were, moreover, dead bodies piled up everywhere, flies buzzing all over them, and no one there thought anything of it [15].

Akira's account of Chapei shares some similarities with those of the Nishizuru district. For example, both accounts emphasizes that the houses are small and crowded, and that the place is the center of filth and evil. In 1937, these points are mentioned again by a Kuomintang lieutenant, who tells Banks about how to reach his parents' captures. The officer describes a scene characterized as a "dense mass of shabby roofs" and "narrow passageways." [15] He goes on to explain that the area is inhabited by factory labourers, and that the landscape is marked by two industrial constructions-East furnace and West furnace. [15] As such, the descriptions of the slums in both novels resonate with each other.

The Kuomintang lieutenant further explains the recent history of Chapei, especially concerning its military implication and housing developments. Then he continues:

I knew almost nothing about the warren until '32, the last time we fought the Japanese. ... Those houses, they were intended for the poorest people. Houses with tiny rooms, row after row, back to back. A warren. ... There was a time when seven or eight people shared such a room. Then as the years went on, families were forced to make partitions, even within these small rooms, to share the rent with another family. And if they still couldn't pay the landlords, they would partition the room further. I remember seeing tiny black closets divided four times, each with a family in it. You do not believe this, Mr Banks, that human being can live like this? [15].

The answer to the question would be no; it is hard to believe that any human could thrive in such an environment. Just as Matsuda calls the slum like Nishizuru "bad fungus" and Ono likens its inhabitants to "ants," [14] the lieutenant employs an animal metaphor by describing Chapei as a "warren." He also calls it "ant's nest." [15] His account of how the homes have been divided into smaller parts reminds one of stories from Nishizuru, where thin paper and cloth are used as partitions. In stark contrast to Nishizuru, however, the Kuomintang officer makes it clear that the homes are meant for the poorest people and that, rent prices continuously rise. While a poor district like Nishizuru canvases the entire city, Chapei develops inward. In other words, the crisis of living is contained within the area, making the place the sole source of trouble.

In a more literal sense, Chapei is in a crisis of existence because the area has been the actual site of war. Japanese militia has bombed it, and guerrilla warfare between Japanese and Chinese troops (both Kuomintang and Communist) has occurred there. Despite all these threats, people cannot live anywhere else because of extreme poverty and territorial agreement between Western forces. On the way to his parents' captures, Banks witnesses the destruction of the area and encounters native inhabitants of Chapei. However, what claims to have seen is limited in scope of what the lieutenant described earlier, including the makeshift homes, amazingly thin partitions, and "overwhelming stink of excrement" in the darkness [15].

Ishiguro makes another self-reference to his previous work concerning the protagonist's survival in an unknown world. When Banks comes to the site where some children have gathered and are poking something with sticks, this something turns out to be a man-a Japanese soldier-who Banks mistakenly identifies as his childhood friend, Akira. [15] After his reunion with Akira, who he used to enact his father's rescue with, Banks neglects all the claims from the local Chinese that the soldier killed their relative, and ventures to get to the house with "Akira" as his guide. While Ono produces two artefacts from his experience in the Nishizuru district, Banks recollects imaginary scenarios in which he rescued his parents. Of course, he does not find his parents where he was told they would be. Chapei was not the center of evil. Later in the novel, it turns out that what Banks called "the case" was not a mystery at all.

As a detective Banks fails to respond to the crisis in two senses. First, he fails to respond to the local Chapei people's call for justice. Instead, he rescues the Japanese soldier that killed their relative so that a mock incarnation of Akira can guide him to his parents. He also fails to restore order in Shanghai because of his anachronism. Banks does not perceive Chapei's condition, but only seeks to restore the lost order of his childhood. In short, Banks is so overcome by his lost past that he cannot see the world in any other way. Moreover, he is totally inadequate as a narrator in his representation of the Chapei crisis in and merely repeats what other have said about the area and its problems. Without those characters like Kuomintang soldiers, the readers are kept away from what is really happening at the war-front. This makes for a curious subversion of the discursive hierarchy. Banks' unreliable narrative is escapist and self-indulgent while local accounts are more reliable and direct. This transforms the crisis into a grotesque fable. Banks makes up the crisis, fails to solve the case, and fails to address the real crisis threatening the lives of the people in Chapei people.

\section{CONCLUSION}

This paper examined the representation of crisis in Kazuo Ishiguro's Artist and Orphans. As we mentioned, both novels' narrators were unable to fully articulate the meaning of poverty; instead they manipulate their encounters in the slum for their own purposes. Masuji Ono rewrites poverty in the artwork with a nationalist bias to downplay the plight of Nishizuru's poor youth, and Christopher Banks seeks to restore world order by mending his broken family. In this 
way, he completely neglects the real meaning of the Chapei crisis. Both narrators' perception of the world and its ongoing crises are unreliable. In this respect, the novel suggests that the issue of poverty, or its allusion to the condition of division in England, can never properly addressed or discussed in society.

Thomas Carlyle mentions in his discussion of the "Condition of England" that the poor working class has no means to represent themselves. [13] In one sense, he refers to the fact that working class has no franchise. However the issue of representation can be extended to include discourse formation. The poor people do not produce their own self-representation; they are always represented by someone who can relegate them into a set discourse. This kind of manipulative process can be observed in Masuji Ono's creation of two propaganda pictures out of his experience in Nishizuru district. For Christopher Banks, stories of poverty and depravity in Chapei justify his misleading story concerning the mysterious disappearance of his parents. Both cases suggest how the crisis, or the state of the nation, is managed and contained in within the limit of epistemology, and in such a limit, Ishiguro subtly include his criticism on liberal government.

\section{REFERENCES}

[1] T. Carlyle, Past and Present, London: Chapman and Hall, 1894.

[2] W. Allen, The English Novel: from the Pilgrim's Progress to Sons and Lovers, London: Penguin, 1991.

[3] M. Bradbury, The Modern British Novel 1878 -2001, London: Penguin, 2001.

[4] J. M. Guy and I. Small, The Routledge Concise History of Nineteenth-Century Literature, London: Routledge, 2011.

[5] F. Kermode, Essays and Fiction 1971-82, London: Routledge and Kegan Paul, 1983.
[6] D. Lodge, After Bakhtin: Essays on Fiction and Criticism, London: Routledge, 1990.

[7] A. Rosen, The Transformation of British Life 1950-2000, Manchester: Manchester University Press, 2003.

[8] P. Clarke, Hope and Glory: Britain 1900-2000, London: Penguin, 2004.

[9] A. Vorda and K. Herzinger, "An interview with Kazuo Ishiguro, in S. Kelman, Ishiguro in Toronto," in Conversations with Kazuo Ishiguro, 2008, pp. 66-88.

[10] G. Mason, “An interview with Kazuo Ishiguro," in Conversations with Kazuo Ishiguro, S. F. Wong and B. Shaffer, Eds. Jackson: University Press of Mississippi, 2008, pp. 3-14.

[11] K. Ishiguro and K. Oe, "The novelist in today's world: A conversation," in Conversations with Kazuo Ishiguro, S. F. Wong and B. Shaffer, Eds. Jackson: University Press of Mississippi, 2008, pp. 52-65.

[12] L. B. Frumkes, "Kazuo Ishiguro," in Conversations with Kazuo Ishiguro, S. F. Wong and B. Shaffer, Eds. Jackson: University Press of Mississippi, 2008, pp. 189-193.

[13] T. Carlyle, Critical and Miscellaneous Essays, London: Chapman and Hall, 1899.

[14] K. Ishiguro, An Artist of the Floating World, London: Faber and Faber, 1989.

[15] K. Ishiguro, When We Were Orphans, London: Faber and Faber, 2000.

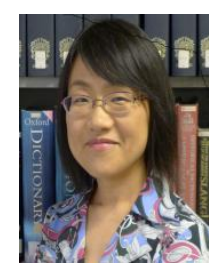

Motoko Sugano was born in Tokyo, Japan on the August 18, 1966. Motoko earned the following degrees: bachelor of Arts in Literature (Waseda University, Tokyo, Japan, March 2000); master of Arts in English Literature, Waseda University, March 2003); master of arts (research) in English (University of New South Wales, Sydney, Australia, February 2006). Major field of study: British literature. She now teaches English at the School of Literature, Tsurumi University, Yokohama, Japan. Her publications include; "The Condition of England Novel Revisited: David Lodge's Nice Work," Kookmin University Journal of Language and Literature, vol.30, no.1, pp. 167-188, 2001; “Putting One's Convictions to the Test": Kazuo Ishiguro's An Artist of the Floating World in Japan," in Kazuo Ishiguro: New Critical Visions of the Novels, Barry Lewis and Sebastian Groes, Eds. Basingstoke: Palgrave Macmillan, 2011, pp. 69-81. Ms. Sugano is a member of the English Literary Society of Japan. 